\title{
FILOZOFICZNE PARADOKSY NUDY
}

\author{
Maria Pleskaczyńska
}

Katolicki Uniwersytet Lubelski

Nuda należy do ogólnie znanych i częstych ludzkich doświadczeń. Jako powszechne ludzkie doświadczenie bywa przez filozofów uznawana za istotny element ludzkiej kondycji. Rozumiana i opisywana jest często jako coś przykrego, niechcianego, czego ludzie starają się uniknąć. Choć bywa nieprzyjemna i dokuczliwa, nie można uznać, że jest nieważna - stanowi istotne doświadczenie egzystencjalne, którego analizy pozwalaja dowiedzieć się czegoś o człowieku, lepiej ludzką kondycję zrozumieć (zob. Svendsen 2005). Nuda bywa przedmiotem dociekań różnych dyscyplin: psychologii, socjologii, nauk kognitywnych, problemu tego nie lekceważy także filozofia. Choć nigdy nie było to zagadnienie „pierwszoplanowe”, w refleksji filozoficznej niejednokrotnie pojawiały się analizy nudy, choćby u Blaise’a Pascala, Friedricha Nietzschego, Sørena Kierkegaarda, Martina Heideggera czy Vladimira Jankélévitcha. Niezwykle ważną współczesną praca o nudzie jest monografia autorstwa Larsa Svendsena, stanowiąca opracowanie filozofii nudy. Pomimo popularyzatorskiego charakteru i niewielkich rozmiarów, ważny i inspirujący dla badaczy tego zjawiska okazuje się także mini-wykład o nudzie autorstwa Leszka Kołakowskiego.

Na gruncie filozofii niezwykle trudno jest zdefiniować nudę. Można uznać, że jest to fenomen związany z pewnym elementarnym brakiem odczuwanym brakiem sensu (Svendsen 2005, Kołakowski 2009). Relację zachodzącą między owym brakiem a nudą Svendsen określa jako skomplikowaną i niejednoznaczną - nie jest jasne, czy świat wydaje się tracić sens, gdy podmiot jest znudzony, czy raczej podmiot zaczyna się nudzić wówczas, gdy świat jawi mu się jako bezsensowny (2005: 17-18). U człowieka znudzonego następuje „wycofanie sensu” - potrzeba sensu czy celowości nie jest zaspokojona. Powiązany z nudą brak sensu może powodować apatię i odbierać poczucie spełnienia (tamże: 30). Przy tworzeniu definicji nudy trudno oprzeć się na jakimś jej pozytywnym elemencie czy wymiarze 
(zob. Svendsen 2005). Claude Adrien Helvétius uznawał nudę za chorobę duszy (Helvétius 1989: 673, za: Markowski 1999: 171), Kierkegaard pisał, że jest ona zbudowana na pustce - spoczywa na wślizgującej się w byt nicości (1982). Schopenhauer określał nudę jako odczucie pustki istnienia (1995), Josif Brodski - jako język typowej rzeczywistości (1996), natomiast Józef Tischner - jako „sposób przeżywania czasu pustego - czasu, który niesie zwykłe «nic»" (1993: 57). Nuda jest ludzkim doświadczeniem - nie istnieje sama w sobie, w oderwaniu od jej przeżywania, chociaż można ja także przypisać postrzeganym przedmiotom oraz osobom (zob. Kołakowski 2009). Należy jednak zauważyć, że dzieje się to na zasadzie uogólnienia konkretnego doświadczenia.

Przeciwieństwem nudy jest ciekawość, żądza wiedzy, pragnienie urozmaicenia nakazujące ludziom różnych czasów i kultur poszukiwać czegoś, co przełamie codzienną rutynę (Markowski 1999). Nuda pojawia się wówczas, gdy brak motywacji lub możliwości na poznanie bądź przeżycie czegoś nowego, gdy człowiek przestaje czegokolwiek nowego oczekiwać, gdy występuje powtarzalność, monotonia i rutyna. Zdaniem Kołakowskiego nuda stanowi cenę, jaką płacimy za ciekawość świata, czyli instynkt nakazujący dążenie do poznawania czegoś nowego dla samego tylko poznawania czy rozwoju - bez nudy nic nie byłoby warte poznania (2009: 99). Zwykle nuda pojawia się, gdy nie możemy robić tego, co chcemy, bądź gdy musimy robić coś, na co nie mamy ochoty, a więc wtedy, gdy zewnętrzne czynniki uniemożliwiają zaspokojenie naszej ciekawości (zob. Svendsen 2005).

Wydaje się jednak, że nuda jest fenomenem kulturowym, a nie czymś zakorzenionym w ludzkiej naturze. Prawdopodobnie nuda w znanej nam dziś postaci nie towarzyszyła ludzkości od początku jej dziejów, stanowi raczej wynalazek nowoczesności, liczący kilka wieków - jest więc cechą rozwiniętej kultury. Do jej rozkwitu przyczynił się pewien poziom dobrobytu i spokoju. Z pewnością ludzie, podobnie jak obecnie, nudzili się we wcześniejszych epokach, nie był to jednak doniosły problem - nudy nie badano, nie opisywano, nie przedstawiano w sztuce. Trzeba jednak zauważyć, że za ważne i doniosłe uważano w dawniejszych czasach odpowiedniki nudy - acedię i melancholię. Według Svendsena we wcześniejszych wiekach dominowała nuda sytuacyjna, towarzysząca określonym momentom czy czynnościom, podczas gdy obecnie często mamy do czynienia także z nuda egzystencjalną, odnoszącą się do całości życia, płynącą z braku poczucia jego sensu (2005: 21). Problemem współczesności okazuje się nadmierne skupienie na tym, co interesujące, innowacyjne, oryginalne - zamiast skupienia na tym, co wartościowe. Poza tym dzisiejsza nuda, inaczej niż kie- 
dyś, jest zdemokratyzowana - dopada nie tylko uprzywilejowane elity, ale wszystkich ludzi, niezależnie od ich pozycji czy stanu posiadania. Bertrand Russell pisał na początku lat 30. XX wieku, że we współczesności mniej niż we wcześniejszych epokach jest samej nudy, za to zdecydowanie więcej strachu przed nią (1932: 60). Dostrzegał też szczególny rodzaj nowoczesnej nudy, wynikający z oddzielenia populacji miejskich od porządku natury „życia na Ziemi” (tamże: 67-68).

Czesław Miłosz w Ogrodżie nauk opisuje współczesna postać acedii strach przed pustką, apatią, smutkiem - których doznaja wielomilionowe masy (1986). Miłosz uznaje ją za cenę płaconą przez ludzkość za indywidualizm i możliwość dokonywania przez jednostki samodzielnych wyborów w świecie, w którym panuje nadpodaż opinii i ocen, przy równoczesnym braku wytyczonych wartości. Współczesny człowiek okazuje się w gąszczu możliwości, informacji, nacisków i wyobrażeń bezbronny. Chociaż Miłosz nie używa w tym kontekście słowa „nuda”, pisze jedynie o acedii bądź lenistwie, jego intuicje okazują się zbieżne z przedstawianymi przez badaczy nudy (1986). Co ciekawe, współczesnemu rozkwitowi nudy towarzyszy szereg nowych rozrywek służących jej „zabiciu”. Nowinki techniczne, mass-media, treści kultury popularnej czy gry komputerowe nie zawsze są dobrym lekarstwem na nudę. Ze względu na fikcyjność oraz nieuchronną bierność konsumenta moga wręcz potęgować głód sensu, przeżyć i stymulacji (zob. Kołakowski 2009, Rembierz 1999). Substytuty sensu, takie jak kult celebrytów, fascynacja tym, co dziwne i odbiegające od normy, czy przesadne skupienie na treściach podawanych przez media moga być oznakami nudy i pustki. Dość powszechnie przyjmowana przez współczesnych badaczy nudy tezę głosząca, że nuda stanowi fenomen kulturowy, dobitnie przedstawia Svendsen (2005, por. Goodstein 2005). Nie jest do końca jasne, jak do tej tezy ustosunkowany był Kołakowski, gdy podkreślał, że nuda nie tylko wyróżnia ludzi ze świata zwierząt, nie tylko stanowi nieodłączny element człowieczeństwa, ale także samo człowieczeństwo konstytuuje (2009).

Badacze analizujący zjawisko nudy twierdzą często, że dotyczy ona wyłącznie ludzi i jest czymś, co odróżnia nas od zwierząt (zob. Russell 1970: 57, Nisbet 1998: 223). Kołakowski twierdził, że od ludzi nudy nauczyły się także, niejako przez naśladownictwo, psy domowe. Wydaje się jednak, że właściciele zwierząt stosunkowo często odnoszą wrażenie, że one także się nudza. Ich intuicję potwierdzać moga coraz liczniejsze badania nad nudą zwierzęca, pojawiającą się zwłaszcza w sztucznych warunkach - ho- 
dowlach, fermach, schroniskach czy klatkach (Wemelsfelder 1984, Meager, Mason 2012).

Kierkegaard pisał, że nuda jest przerażająco nudna (1982: 38). Osaczająca pustką nie daje się opisać inaczej niż przez odwołanie do niej samej - brak słów adekwatnych do określenia tego dziwnego doświadczenia. Wydaje się, że każdy, komu nuda znana jest z doświadczenia, skłonny byłby zgodzić się ze stwierdzeniem „nuda jest nudna”. Także teoretyczne zajmowanie się nuda może budzić obawy przed tym, że samo okaże się nudna czynnością. Badacze nudy zgodni są co do tego, że nudne jest na ogół to, co powtarzalne, monotonne, przewidywalne (zob. Gadacz 2004, Kołakowski 2009, Svendsen 2005). Filozoficzne analizy nudy okazują się w tym sensie nie-nudne - sa pełne swoistych, rozumianych w znaczeniu miękkim paradoksów - sprzeczności, niespójności czy zestawień kontrastujacych ze sobą treści. W niniejszym tekście w oparciu o dziesięć prostych paradoksów, które można sformułować, badając poglądy różnych autorów, przedstawiony zostanie pewien zarys filozofii nudy. Pozwoli on pokazać, że analizy nudy, choć intuicyjne i wychodzące od doświadczenia przeżywania nudy, zawieraja pewne elementy sprzeczne, a co najmniej nieoczywiste, warte dostrzeżenia i skomentowania.

\section{/// Paradoksalność nudy}

Wydaje się że paradoksalny charakter nudy pozwala wiele powiedzieć o niej samej - zjawisku zarazem powszechnym i nieistotnym, osaczającym i banalnym, trochę wstydliwym, a jednocześnie mogącym ludzi wyróżniać ze świata zwierząt. Paradoksalna wydawać się może niejednoznaczność i złożoność tego fenomenu, w wypadku którego trudno o jednoznaczne rozstrzygnięcia, który może objawiać się na wiele sposobów, mieć rozmaite przyczyny i skutki. Stanowiąca powszechnie znane doświadczenie, banalna nuda na poziomie teoretycznym zadziwia bogactwem treści, dających się uporządkować w postaci paradoksów. Niektóre z nich mają charakter uniwersalny, odnosić się więc mogą zarówno do nudy sytuacyjnej, jak i egzystencjalnej, dla większości jednak kluczowa będzie kategoria nudy egzystencjalnej, w sposób szczególny inspirująca dla filozofów.

\section{PARADOKS 1}

To, co dla jednego jest nudne, dla drugiego może być fascynujące. 
Doświadczenie nudy jest zawsze indywidualne, nie daje się w pełni zobiektywizować. Trudno mówić o niej jedynie jako o fakcie. Nuda - zawsze czyjaś i jakaś - nieuchronnie zakłada element interpretacji (zob. Dalle Pezze, Salzani 2009). Choć istnieja książki, filmy czy sposoby spędzania wolnego czasu, które powszechnie uchodzą za nudne, istnienie czegoś nudnego w sensie absolutnym (może oprócz całkowitego pozbawienia bodźców, choć nawet ono powoduje inne niż nuda reakcje - ludzki mózg na fakt odcięcia od wrażeń zmysłowych reagować może halucynacjami), co znudziłoby wszystkich bez wyjątku, wydaje się jednak watpliwe. To, co nas nudzi, zależy od indywidualnych doświadczeń, upodobań, zainteresowań, wiedzy. Co więcej, to, co w jednej chwili wydaje się fascynujące, po kilku minutach może stać się nudne (i odwrotnie) (zob. Kołakowski 2009).

\section{PARADOKS 2}

Nudne może być to, co dobrze znane, rutynowe, powtarzające się, ale także to, co nowe, nieznane i niezrozumiałe.

Za nudne uważa się przede wszystkim to, co jest monotonne, co się powtarza, to, w czym brak elementu zaskoczenia. Poznana wcześniej akcja filmu czy książki, o ile nie przywołuje pewnych szczególnych wspomnień bądź emocji, nie przyciaga uwagi. A jednak czasem zachodzi zjawisko odwrotne - zdarza się, że aby się czymś zainteresować, trzeba to zrozumieć, bliżej poznać. Coś na pierwszy rzut oka nudnego - niezrozumiałego, chaotycznego, trudnego - może się okazać fascynujące, jeśli poświęcimy temu nieco uwagi (zob. Kołakowski 2009). Szereg dyscyplin wiedzy - choćby filozofia, ale też nauki ścisłe czy ekonomiczne - w powszechnym odbiorze uchodzi za nudne. Odkrycie, że mogą być niezwykle interesujące, wymaga pewnego zaangażowania, zdobycia przynajmniej podstawowej wiedzy z danego zakresu. Po przeczytaniu kilku stron można się znudzić Władca Pierścieni J.R.R. Tolkiena albo W poszukiwaniu straconego czasu Marcela Prousta, żeby dopiero później „wniknąć” do świata przedstawionego, zrozumieć prawa nim rządzące i się nimi zachwycić. Osobom nieznającym zasad gry w szachy, bilard czy golfa gry te wydaja się nudne, podczas gdy ich pasjonaci wcale na nudę nie narzekają. Co ciekawe, pasjonaci nie odczuwają nudy nawet wtedy, gdy przedmiot ich zamiłowania wymaga wykonywania rutynowych, monotonnych i powtarzalnych ćwiczeń czy sekwencji czynności. Poziom zaangażowania oraz stosunek emocjonalny do wykonywanej czynności okazuje się w tym wypadku skutecznym remedium na 
nudę, ponadto nie ma tu mowy o braku poczucia sensu danej czynności. Dostrzegając element monotonii i rutyny w wielu dziedzinach życia, Russell twierdził, że umiejętność radzenia sobie z nudą i monotonią winno się zdobywać w dzieciństwie, w czasie, gdy niemal wszystkie dni powinny być do siebie podobne, gdyż w dorosłym życiu może się ona okazać niezbędna - bez niej trudno o konsekwencję w dążeniu do osiągania ważnych życiowych celów (1932: 64-65). Także to, co wybrane, wymarzone, najciekawsze i najistotniejsze może wiązać się na jakimś etapie z nudą, dlatego należy być przygotowanym na jej wystapienie - pojawiająca się nuda może być przystankiem na drodze do fascynującego celu.

\section{PARADOKS 3}

Nuda może się wiązać z bezczynnością, ale nudzić mogą także wykonywane czynności.

W Zakończeniu Wolterowskiego Kandyda bohaterowie poszukuja odpowiedzi na wielkie pytanie: czy gorzej jest „doświadczyć wszystkich nieszczęść, przez któreśmy przeszli, czy tkwić tutaj tak bezczynnie?”. Filozof Marcin stwierdza wtedy, że „człowiek zrodzony jest, aby żyć w konwulsjach niepokoju lub też w letargu nudy" (Wolter 1999: 111). Niedługo potem, kierując się radą dobrego starca, znajduje remedium na nudę, sposób czyniący życie znośnym. Owo remedium przy okazji przynosi bohaterom zyski i sprawia, że brat Żyrofla stał się uczciwym człowiekiem. „Pracujmy nie rozumując" - powiada Marcin i zmienia życie swoje i swoich towarzyszy na lepsze (tamże: 114). Dla osiemnastowiecznych filozofów praca, w tym także praca fizyczna, stanowić miała uniwersalne lekarstwo na nudę. W myśl takiego rozumowania człowiek pracowity i zajęty nie ma czasu się nudzić, nie zapada więc na chorobę duszy. Kto pracuje, ten się nie nudzi, a kto się nie nudzi - ten jest szczęśliwy (Markowski 1999: 171).

Wydaje się jednak, że nie można mówić o pełnej skuteczności tego remedium na nudę. Oświeceniowi myśliciele, tacy jak Wolter czy Helvétius, zdawali się utożsamiać nudę z brakiem zajęcia. Rzeczywistość nudy okazuje się tymczasem bogatsza i bardziej złożona. Nudzić może zarówno nadmiar pracy, choćby obiektywnie bardzo ciekawej, jak i nadmiar wolnego czasu. Nuda okazuje się znacznie trudniejsza do zwalczenia niż bezczynność, ponieważ ma charakter egzystencjalny. Nuda wiąże się z nastrojem i uczuciami, które nie znikną od razu po podjęciu czynności mającej ją zabić. Wydaje się, że miał rację Kierkegaard piszący, że praca stanowi remedium 
na bezczynność, ale nie na nudę (1982: 328-329). Charakterystycznego dla nudy braku poczucia sensu nie wyeliminuje pierwsza lepsza czynność czy rozrywka (zob. Kołakowski 2009, Svendsen 2005). Żeby czynność przerwała nudę, musi być dla konkretnego człowieka interesująca, a co więcej, on musi widzieć jej sens. Ludzie mają różną podatność i odporność na nudę i na różne sposoby manifestuja swoje znudzenie. Jako lekarstwa na nudę proponuje się nie tylko rozrywki czy proste czynności, ale także czynności mające nadać życiu sens: znalezienie pasji, realizację w pracy czy działalności charytatywnej, pogłębienie życia duchowego i religijnego (zob. Svendsen 2005). Co ciekawe, można być znudzonym, nie znając przyczyny swojej nudy, a nawet o tym nie wiedząc, nie mając świadomości, że właśnie dopadła nas nuda (Svendsen 2005: 14). Nuda ma wiele oblicz i wiele stopni natężenia - od pewnego dyskomfortu, niezadowolenia, aż po poczucie skrajnego bezsensu i beznadziei. Nuda może osaczać, dopadać, zaskakiwać, atakować - badacze porównują ją do mgły, chłodu czy bezsenności (zob. Heidegger 1977, Svendsen 2005). Może być trudno się jej pozbyć i na nią wpłynąć, może być zarazem bardzo uciążliwa (zob. Svendsen 2005).

\section{PARADOKS 4}

Nuda, nieuchronnie związana z czasem, ma wymiar czasowy, zarazem jednak dąży do „zabicia czasu”.

Kołakowski zauważył, że nudę można przypisać jedynie temu, co jest w czasie rozciagnięte (2009: 94-95). Jankélévitch genezę nudy wywodził z napięcia między czasem fizycznym, nieuchronnie obecnym, na który człowiek nie ma wpływu, a odczuwanym czasem psychologicznym (Jankélévitch 1963, cyt. za: Dalle Pezze, Salzani 2009). Zauważyl, że w wypadku nudy - podobnie jak w wypadku czekania - czas ograniczony jest do czystej gęstości tygodni, miesięcy czy lat, na którą nie można wpłynąć. Człowiek pragnie taki czas zabić, przespać bądź zapełnić rozrywkami (zob. Jankélévitch 2005: 40). Gdy się nudzimy, percepcja czasu zostaje rozciągnięta - mamy wrażenie, że czas płynie bardzo wolno, że się wydłuża. Taki ujednolicony, zatrzymany czas staje się przykry, trudny, nieznośny, dlatego ludzie dążą do jego przyspieszenia czy wręcz pozbycia się go, jak zwykliśmy mówić - do zabicia czasu, zlikwidowania jego dojmującego charakteru. Michel de Montaigne twierdził, że w jego prywatnym słowniku, nieco przewrotnie, „spędzanie czasu” znaczyłoby tyle, co „zabicie”, unicestwienie go, i odnosić by się miało do czasu przykrego, obmierzłego 
(1985: 323). Myśl tę rozwija Michał Paweł Markowski, przyrównując Montaigne’owskie „spędzanie czasu” nudy do „spędzania płodu” (1999: 162). Jak się wydaje, ta metafora wyjattkowo trafnie ukazuje siłę negatywnych emocji, jakie pociaga za sobą nuda. Do zabicia czasu mogą służyć różne czynności i rozrywki - jeśli podejmowane są z pewną desperacja, kiedy nuda staje się nieznośna, często okazać się mogą przypadkowe, a tym samym nieskuteczne (zob. Gadacz 2004).

Czym innym od zwykłej, codziennej nudy okazuje się jednak skrajna, radykalna nuda. Skrajna nuda to doświadczenie bezczasowości - nie tyle spowolnienia czy nawet zatrzymania czasu, ile nicości. Jego przejawem jest duchowa pustka. To doświadczenie bliskie śmierci, wrażenie skrajnego bezsensu życia, końca czasu i ogromnej samotności (zob. Kierkegaard 1982, Gadacz 2004, Schopenhauer 1995). W jego wypadku człowiekowi brak nadziei czy to na zabicie czasu, czy na to, że czas wróci do normy.

\section{PARADOKS 5}

Nuda wiąże się ze świadomością i refleksyjnością, a zarazem odbiera zdolność pogłębionej refleksji.

Jeśli przyjąć, że nudzą się tylko ludzie, to właśnie dlatego, że cechuje ich samoświadomość i refleksyjność. Bycie znudzonym (nawet jeśli nie jest uświadomione) zakłada pewien namysł nad soba, zdolność do odczuwania niezadowolenia, niespełnienia i braku sensu, zdolność do wyższych pragnień i aspiracji. Niektórzy autorzy uznają także, że nuda może otwierać na głębszą refleksję i pogłębiać samoświadomość. Nietzsche, pisząc o „wczasie i próżnowaniu”, w opozycji do „pośpiechu pracujących” oraz kultu pracy, ustawia radość próżnowania i życie kontemplacyjne (2003). Według Heideggera w głębokim znudzeniu - stanie, w którym nie jesteśmy zajęci ani rzeczami, ani soba, w którym wszystko jest nam obojętne - ujawnia się całość bytu (1977). Także Brodski podkreśla wartość nudy, która będąc inwazją czasu w ludzki system wartości, pozwala dostrzec nieskończoność czasu i naszą znikomość (1996). Uświadomienie ich sobie nie musi być doświadczeniem negatywnym, towarzyszy mu bowiem zrozumienie tego, że w nieskończoności brak miejsca na życie czy emocje. Im bardziej coś skończone, tym bardziej przepełnione życiem, radością i zrozumieniem. Nudzie towarzyszy przeczucie nieożywionej nieskończoności, które przesądza o żarliwości ludzkich uczuć. Brodski jako zaletę nudy (podobnie jak cierpienia, udręki i poczucia własnej znikomości) postrzega pewność, że w po- 
rządku poznawczym nie zostało się oszukanym (1996). Ta myśl pozwala sparafrazować słowa Kartezjusza i stwierdzić: „nudzę się, więc jestem”.

Z drugiej strony nuda może odbierać poczucie sprawczości, pewność i jeszcze bardziej oddalać wszelki sens, przyczyniać się do obniżenia aspiracji, rodzić apatię i potęgować zniechęcenie. Nuda wciaga i osacza, pogłębia się, sprawiając, że człowiek przestaje szukać czegokolwiek nowego, przestaje się czegoś nowego spodziewać (zob. Svendsen 2005).

\section{PARADOKS 6}

Nuda jest zarazem banalna i fascynująca.

Nuda, będąc z pozoru podobną do doniosłych filozoficznych i psychologicznych kategorii, sama doniosła nie jest. Melancholia, acedia, depresja czy nostalgia zdają się mieć coś, czego nudzie brak. Acedia - średniowieczna poprzedniczka nudy - była kategorią religijna, mająca odniesienie do spraw ostatecznych, co niewattpliwie dodawało jej powagi. W melancholii dopatrywano się przejawu głębi intelektu i życia duchowego. Depresja klasyfikowana jest jako jednostka chorobowa, której groźne konsekwencje sa powszechnie znane. Nuda natomiast pozostaje banalna - nie porusza, nie pociaga, budzi (poza skrajnymi przypadkami) raczej niechęć niż przerażenie, wydaje się trochę niepoważna. Jak stwierdza Kołakowski, nudy nie da się nazwać cierpieniem (2009: 94). Mimo tego braku powagi pozostaje przedmiotem badań wielu dyscyplin naukowych, a także tematem dzieł literatów i artystów. Z jednej strony, może się wydawać, że nuda sama w sobie jest nudna i że w obliczu szeregu poważnych życiowych problemów nie warto poświęcać jej uwagi, z drugiej zaś, okazuje się, że nuda przyciaga, budzi zainteresowanie - prawdopodobnie dlatego, że okazuje się niezwykle powszechna i... ludzka. Jako taka może pozwalać lepiej zrozumieć człowieka i jego egzystencje (zob. Svendsen 2005).

\section{PARADOKS 7}

Przyjęło się twierdzić, że nuda pojawia się w warunkach spokoju i bezpieczeństwa, a zarazem spokój odbiera ${ }^{1}$.

\footnotetext{
1 Twierdzenie to jest powszechne w filozofii nudy, należy jednak pamiętać, że nie zgodziliby się na nie badacze z zakresu innych dyscyplin, np. ci, którzy analizują kategorię nudy wojennej.
} 
Jeśli - zgodnie z opinią badaczy - przyjąć, że zwierzęta faktycznie się nie nudzą, to trzeba uznać, że dzieje się tak dlatego, że nie wydatkują na darmo energii. Gdy są bezpieczne, spokojne i najedzone, jest im dobrze, mogą spokojnie odpoczywać i gromadzić siły ${ }^{2}$. Także w ludzkim życiu, tam gdzie pojawia się zagrożenie, strach, niebezpieczeństwo, choroba, brak jest miejsca na nudę. Nuda zakłada stabilność, pewien dobrostan, zaspokojenie podstawowych życiowych potrzeb. W obliczu poważnych problemów nuda wydaje się raczej marginalnym zmartwieniem (zob. Kołakowski 2009).

A jednak, nuda może niepokoić, zaburzać spokój wewnętrzny. Związany z nią brak poczucia sensu i brak spełnienia w wymiarze osobowym - mimo pewnej trywialności nudy - moga być dramatyczne. Nuda może rodzić bardzo konkretne i poważne zagrożenia: uzależnienia, zaburzenia zdrowia psychicznego, ryzykowne zachowania mające dostarczać wrażeń, agresję i przemoc (zob. Svendsen 2005: 17-18, Rembierz 1999: 180). Szczególnie dobitnie o dramatycznym wymiarze nudy pisał Pascal, który twierdził, że nie ma nic równie nieznośnego, jak prowadzące do uświadomienia sobie własnej nicości i zależności, rodzące nudę, smutek, żal i rozpacz zażywanie „pełnego spoczynku, bez namiętności, bez spraw, rozrywek, zatrudnienia” (1989: 57). Pojawiająca się w wyniku spokoju i bezczynności nuda rodzi najgłębszy, najbardziej dramatyczny egzystencjalny niepokój. W koncepcji Pascala z dojmującego, dramatycznego doświadczenia nudy wydobyć człowieka - a tym samym przywrócić mu spokój - mógłby jedynie Bóg (1989, por. Markowski 1999: 169).

\section{PARADOKS 8}

Nuda może pojawić się wskutek niedosytu wrażeń, przeżyć, nowości, ale też w następstwie nadmiaru wrażeń.

Może rodzić się z pełni, bazować na przesycie (zob. Nisbet 1998: 224). Człowiek pragnie wrażeń, nowości, szuka czegoś ciekawego, do czegoś ważnego dla siebie dąży. Spełnienie potrzeb, oczekiwań i aspiracji może rodzić satysfakcję, ale też - zamiast niej bądź krótko po niej - nudę. Tadeusz Gadacz pisze w tym kontekście o nudzie dni świątecznych, wynikającej z zaspokojenia planów i marzeń. Nagle, gdy nie ma już na co czekać i do

\footnotetext{
${ }^{2}$ Ów stan spokoju i niewydatkowania energii można też uznać za przejaw nudy zwierzęcej, należy jednak wówczas zauważyć, że jest to zupełnie inna nuda niż ta opisywana przez filozofów w odniesieniu do ludzkiego życia. Apatycznej nudy zwierzęcej nie cechuje element braku, nie towarzyszy jej poczucie niespełnienia czy choćby niezadowolenia.
} 
czego się szykować, gdy wszystko potoczyło się zgodnie z planem, to, co jeszcze niedawno było upragnione, nagle okazuje się nudne i puste. $\mathrm{Na}$ podobnej zasadzie ludzie wyobrażaja sobie niebo jako miejsce, w którym jest nudno (Gadacz 2004). Nuda nieba pojawia się także w myśli Schopenhauera, który stwierdza, że „życie biegnie wahadłowym ruchem, między bólem i nudą, są to faktyczne jego ostateczne składniki. Wyrazić się to musiało też bardzo osobliwie w taki sposób, że kiedy człowiek przeniósł wszystkie cierpienia i męki do piekła, dla nieba nie pozostało już nic poza nudą" (1994: 474). Nudę odnoszą autorzy nie tylko do porządku nieba, ale także do utopii - Svendsen zauważa, że stawia ona wewnętrzną granicę wszelkim utopiom (2005). Kołakowski natomiast, pisząc o utopii, stwierdza, że byłaby ona przyczyną końca ciekawości (2009).

\section{PARADOKS 9}

Filozofowie, uznając nudę za fenomen charakterystyczny wyłącznie dla ludzi, przypisywali ja zarazem Bogu czy bogom.

Nudzie, postrzeganej zwykle jako banalna i trywialna, ludzie przypisywali czasem ogromną moc i podkreślali jej znaczenie. Podczas gdy w myśli Pascala Bóg byłby jedynym źródłem pomocy w sytuacji ludzkiej nudy, inni filozofowie rozciagali tę sytuację na istoty wyższe. Podatność bogów na nudę stanowić może czynnik jakoś ją nobilitujący. Nietzsche stwierdzał, że z nuda nawet bogowie walczyli daremnie (2004: 47). Piewca śmierci Boga, odnosząc się do Księgi Rodzaju, pisał, że „stary Bóg” nudził się w raju, dlatego stworzył zabawnego człowieka. Człowiek także się nudził, dlatego Bóg stworzył dla niego zwierzęta. Gdy ich obecność nie rozbawiła Adama, stworzona została Ewa (tamże). Prezentowaną przez Nietzschego nudę Boga Gadacz interpretuje w wymiarze pozytywnym, jako łagodny stan bliski odpoczynkowi, pozwalający zebrać siły, wyciszyć się, zająć się swoim wnętrzem (Gadacz 2004: 157-158).

Kierkegaard - zagorzały przeciwnik nudy - w eseju Gospodarka przemienna pisał, że nuda jest „korzeniem wszelkiego zła” (1982). Ironicznie stwierdzał, że społeczeństwo trzeba przed nią chronić, zapewniając mu atrakcyjne rozrywki. Inaczej nuda świata wzrasta, a wtedy zalewa go zło. Najlepszym królem - w obronie przed nuda - miałby być ten, kto opowie najśmieszniejszy dowcip, a jego następca - ten, kto stworzy ku temu stosowna okazję. Kierkegaard, który przyjął w eseju pierwotna zasadę, zgodnie z którą wszyscy ludzie są nudni, przyznawał nudzie, mimo jej spokojnej 
i zrównoważonej natury, ogromną niszczycielską moc. Nudę uznawał nie tylko za przynależną Bogu, ale i demoniczną, mogącą opętać. W swoistym, autorskim micie, podobnie jak Nietzsche, opisywał, jak od początku dziejów nuda zalewała świat: bogowie się nudzili, więc stworzyli Adama, ten się nudził, więc powstała Ewa. Pierwsi ludzie nudzili się wspólnie, a później wraz z Kainem i Ablem. Owocem nudy w czasach biblijnych okazać się miała wieża Babel, a w czasach Kierkegaarda - stabilna, oszczędna i potwornie nudna polityka (zob. Kierkegaard 1982: 324-327).

Kierkegaard pisał, że pomimo bezczynności nie nudzili się bogowie olimpijscy - pozostawali szczęśliwi, nie odczuwając nudy. Tym samym dowartościował bezczynność, uznając próżniactwo za podstawę prawdziwie boskiego życia - ten, komu brak zrozumienia dla lenistwa, miałby nie podnieść się jeszcze do prawdziwie ludzkiego poziomu (zob. Kierkegaard 1982: 329).

Przypisanie nudy bogom (nawet niezbyt życzliwie postrzeganym) podkreśla jej wagę w ludzkim życiu, a także czyni ją czymś przynależnym wybranym. Nobilitująca, już nie degradująca, nuda nie jest w świetle tej intuicji jedynie wstydliwą ludzką słabością, ale czymś wyrafinowanym, co może człowieka wyróżniać jako istotę doskonalszą, uprzywilejowaną, zdolną do posiadania wysublimowanych problemów i bogatego życia wewnętrznego - prawdziwie stworzoną na obraz i podobieństwo Boga, także tego znudzonego, rodem z wyobrażeń filozofów.

\section{PARADOKS 10}

Nuda może prowadzić do dobra albo do zła, mieć dobre albo złe skutki.

Bywa korzeniem zła, ale bywa również przyczyną dobrych i pożytecznych odkryć czy wynalazków, mogą się z niej rodzić dobre pomysły i rozwiązania. Russell uznawał nudę za istotny motyw kierujący historią (1970: 57), Robert Nisbet zaś opisywał ją jako jedną z „najbardziej uporczywych i powszechnych” sił wpływających na ludzkie zachowanie (1998: 223). Jeśli ktoś chce przezwyciężyć nudę - może próbować zmienić świat i siebie samego na lepsze. Nuda może motywować nie tylko do zła, ale i do dobra (zob. Svendsen 2005). Jak stwierdza Kołakowski, ,uczucie nudy rozbudza, oczywiście, potrzebę wyjścia z nudy, a to wyjście może być zarówno niszczycielskie, jak twórcze [...]" (2008: 99). Nuda może więc być pasywna albo aktywna, pogłębiać bierność albo budzić kreatywność. Istnieją różne rodzaje, klasyfikacje nudy: można mówić o nudzie sytuacyjnej, egzysten- 
cjalnej, pasywnej i aktywnej, niszczącej i konstruktywnej. Nuda może prowadzić do alienacji albo przeciwnie, do nowych społecznych rozwiązań, do kontaktu, bliskości (zob. Svendsen 2005, Brodski 1996). „Niszczycielskie wyjście z nudy" okazuje się zdaniem Kołakowskiego (z czym intuicyjnie trudno się nie zgodzić) łatwiejsze, nie znaczy to jednak, że człowiek jest na to, co łatwe, skazany (2008: 99).

Nuda może rodzić obojętność albo pobudzać do stawiania fundamentalnych pytań. Zdaniem Heideggera to z niej bierze się pytanie o to, skąd wziął się świat (2004). Nawiązując do autora, można pokusić się o nieco żartobliwe stwierdzenie, że to z nudy wzięła się filozofia. Nastrój nudy może prowokować pytanie o bycie, a w głębokim znudzeniu, w obliczu którego wszystko staje się obojętne, ujawnia się całość bytu (zob. Heidegger 2004, Sobota 2012).

Nuda nie tylko może być korzeniem zła, ale też może zło niweczyć. Czasem nawet nie za sprawą szczególnie dobrego wpływu, ale choćby dlatego, że zło, podobnie jak wszystko, co znane, oswojone i powtarzalne, także może nudzić. Nisbet przytacza w tym kontekście przykład zaprzestania palenia czarownic - jego zdaniem ostatecznie zaniechano tej praktyki, bo wszystkie paliły się tak samo (Nisbet 1998: 227). Według Kołakowskiego nuda może być godna pochwały, ale i niebezpieczna, w zależności od tego, do czego w danym przypadku będzie człowieka prowadzić (2009). W odniesieniu do niej nie można mówić o jednoznacznym wymiarze, nie ma też jednoznacznych rozstrzygnięć. Jak się wydaje, nie należy na nudę patrzeć jako na katastrofę czy nieszczęście, nie należy także jej bagatelizować ani podchodzić do niej nazbyt optymistycznie, należy natomiast spojrzeć na nią jako na punkt wyjścia do zmian, nowych decyzji, rozwiązań, relacji, czynów i postaw. Tak rozumiana nuda staje się momentem budzenia się ludzkiej sprawczości i odpowiedzialności.

\section{/// Uwagi końcowe}

Analizy kolejnych filozofów układają się w paradoksy nie dlatego, że są sprzeczne, błędne czy zawiłe, ale dlatego, że ukazują różne aspekty niezwykle złożonego zjawiska, jakim jest nuda. Paradoksy pojawiają się niejednokrotnie w obrębie myśli poszczególnych autorów, nawet bez zestawiania ich analiz z dociekaniami innych filozofów (bodaj najbardziej na pojawiające się w kontekście nudy sprzeczności zwraca uwagę Kołakowski). Przytoczone powyżej 10 paradoksów, będące pewną ilustracją poglądów autorów zajmujących się tym problemem, stanowić może skromne preludium do 
filozofii nudy. Nuda - zjawisko, które każdego dosięga, a które zarazem przez nikogo nie jest chciane i oczekiwane - okazuje się skomplikowana i wielopłaszczyznowa. Nuda nie jest więc tak banalna, jak mogłoby się początkowo wydawać.

Niezależnie od tego, jak bardzo ludzie nie lubią się nudzić, jak silną mają skłonność do uciekania przed nudą i jak duży wzbudza ona opór, nuda pozostaje elementem ludzkiej kondycji. Nie sposób odmówić Svendsenowi racji, gdy pisze, że z pewną dawką życiowej nudy należy się pogodzić (2005: 151-152). Brodski proponuje kontrowersyjną z pozoru metodę radzenia sobie $z$ nuda - pogrążenie się w niej, ostatecznie prowadzące do zrozumienia roli ludzkich uczuć. Od niego zaś jest już bardzo blisko do remedium na nudę - namiętności (1996). Obok pogodzenia się z pewna jej dawką, należy oczywiście nudzie zapobiegać - rozwijać zainteresowania, wiedzę, ciekawie spędzać czas. Samej nudy nie należy jednak się przesadnie obawiać, nie należy też interpretować jej nazbyt pesymistycznie. Ostatecznie nuda, w całej swojej paradoksalnej niejednoznaczności i złożoności, zawsze okazuje się czyjaś - konkretna, nieuchronnie subiektywna, odczuwana przez konkretnego człowieka w konkretnym czasie i danej sytuacji. W zdecydowanej większości sytuacji to podmiot ma władzę nad swoją nuda, nie ona nad nim ${ }^{3}$. Co za tym idzie, od niego ostatecznie zależy, jak wyjściowa sytuacja nudy się rozwinie i co z niej wyniknie - czy stanie się ona Kierkegaardowskim korzeniem zła, czy wręcz przeciwnie - zalążkiem dobra - kreatywności, oryginalności, wiedzy, refleksyjności, świadomie podejmowanej odpowiedzialności, docenienia roli uczuć i pogłębienia relacji międzyludzkich.

Bibliografia:

/// Brodski J. 1996. Pochwała nudy, tłum. A. Kołyszko, M. Kłobukowski, Wydawnictwo Znak.

/// Dalle Pezze B., Salzani C. 2009. Introduction. The Delicate Monster: Modernity and Boredom, [w:] Essays on Boredom and Modernity, red. B. Dalle Pezze, C. Salzani, Editions Rodopi B.V, s. 5-33.

\footnotetext{
${ }^{3}$ Sytuacjami, w których tak nie jest, okazać się mogą przypadki deprywacji sensorycznej zewnętrznego, często brutalnego pozbawienia bodźców oraz najgłębszej, bliskiej depresji, nudy egzystencjalnej.
} 
/// Gadacz T. 2004. Nuda, [w:] tenże, O umiejetności ¿̇ycia, Wydawnictwo Znak, s. 156-166.

/// Goodstein E. 2005. Experience Without Qualities: Boredom and Modernity, Stanford University Press.

/// Heidegger M. 1977. Czym jest metafizyka?, tłum. K. Pomian, [w:] tegoż, Budować, mieszleać, myśleć: eseje wybrane, Czytelnik, s. 27-47.

/// Heidegger M. 2004. Bycie i cras, tłum. B. Baran, Wydawnictwo Naukowe PWN.

/// Jankélévitch V. 2005. Forgiveness, tłum. A. Kelley, The University of Chicago Press.

/// Kierkegaard S. 1982. Albo-albo, tłum. J. Iwaszkiewicz, t. 1, Państwowe Wydawnictwo Naukowe.

/// Kołakowski L. 2009. Mini wykkłady o maxi sprawach: træy serie, Wydawnictwo Znak, s. 94-101.

/// Markowski M. 1999. Anatomia ciekawości, Wydawnictwo Literackie.

/// Meagher R., Mason G. 2012. Environmental enrichment reduces signs of boredom in caged mink, „PLOS”, nr 11(7), s. 1-10.

/// Miłosz Cz. 1986. Ogród nauk, Redakcja Wydawnictw Katolickiego Uniwersytetu Lubelskiego.

/// Montaigne M. 1985. Próby, tłum. T. Żeleński (Boy), t. 3, Państwowy Instytut Wydawniczy.

/// Nietzsche F. 2003. Wiedza radosna, tłum. L. Staff, Zielona Sowa.

/// Nietzsche F. 2004. Antychryst. Próba krytyki chræesécijaństwa, tłum. L. Staff, Zielona Sowa.

/// Nisbet R. 1998. Nuda, [w:] tenże, Przesady: stownik filozoficzny, tłum. M. Szczubiałka, Fundacja Aletheia, s. 223-229.

/// Pascal B. 1989. Myśli, tłum. T. Żeleński (Boy), Instytut Wydawniczy PAX.

/// Rembierz M. 1999. Nuda - fikcja - agresja. O przemocy jako przejawie kulturowej bezdomności - szkic z antropologii filozoficznej i filozofii wychowania, [w:] Młodzież w sytuacji zmian gospodarczych, edukacyjnych, społecznych $i$ kulturowych, 
red. W. Kojsa, R. Mrózek, R. Studenski, t. 2, Uniwersytet Śląski - Filia w Cieszynie, s. 175-190.

/// Russell B. 1932. The Conquest of Happiness, George Allen \& Unwin LTD.

/// Schopenhauer A. 1994. Świat jako wola i przedstawienie, ttum. J. Garewicz, Wydawnictwo Naukowe PWN.

/// Schopenhauer A. 1995. Metafizyka ¿̇ycia i śmierci, tłum. J. Marzęcki, Ethos.

/// Sobota D. 2012. Źródta i inspiracje heideggerowskiego pytania o bycie, t. 1, Fundacja Kultury Yakiza.

/// Svendsen L. 2005. A Pbilosophy of Boredom, tłum. J. Irons, Reaktion Books.

/// Tischner J. 1993. Spowiedź rewolucjonisty: czytajac „Fenomenologie ducha” Hegla, Wydawnictwo Znak.

/// Voltaire F. 1999. Kandyd; Prostaczek, tłum. T. Żeleński (Boy), Club International del Libro, s. 5-114.

/// Wemelsfelder F. 1984. Animal Boredom: Is a Scientific Study of the Subjective Experiences of Animals Possible?, [w:] Advances in Animal Welfare Science, red. M.W. Fox, L. Mickley, Martinus Nijhoff Publishers, s. 115-154.

\section{/// Abstrakt}

Fenomen nudy znany ludziom z doświadczenia bywa przedmiotem badań różnych dyscyplin, w tym filozofii. Za istotny element nudy autorzy uznają poczucie braku sensu, uczucie pustki. Za nudne zwykło się uważać to, co banalne, powtarzalne, nieurozmaicone, pozbawione elementu zaskoczenia. Filozoficzne analizy nudy, ukazujące różne jej aspekty, okazują się w tym kontekście nienudne - poglądy różnych autorów (m.in. S. Kierkegaarda, F. Woltera, F. Nietzschego, M. Heideggera, L. Svendsena, L. Kołakowskiego, T. Gadacza) układają się w swoiste paradoksy, pełne elementów kontrastowych i pozornych sprzeczności.

Słowa kluczowe:

nuda, doświadczenie nudy, paradoksy nudy 


\section{/// Abstract}

The phenomenon of boredom, which people know from experience, is also an object of study in various disciplines, including philosophy. The authors consider an essential component of boredom to be the feeling of senselessness, of emptiness. Ordinarily, it is thought that what is banal, repetitive, unvaried, or devoid of the element of surprise is boring. A philosophical analysis of boredom, showing its various aspects, turns out in this context not to be boring - the views of various authors, including Kierkegaard, Wolter, Nietzsche, Heidegger, Svendsen, Kołakowski, and Gadacz form paradoxes of sorts, full of the elements of contrast and apparent contradiction.

Keywords:

boredom, experience of boredom, paradoxes of boredom 